\title{
The quality improvement of Bulgogi using superheated steam and high hydrostatic pressure
}

\author{
Eunmi Kim ${ }^{1 *}$, Sanghee $\mathrm{Seo}^{2}$, Younsang $\mathrm{Choi}^{1}$, Kihong Chun ${ }^{1}$, Eunjung Lee ${ }^{3}$ \\ ${ }^{1}$ Korea Food Research Institute, Sungnam 13539, Korea \\ ${ }^{2}$ Korea Food and Drug Administration, Incheon 22133, Korea \\ ${ }^{3}$ Division of Food Science and Culinary Arts, Shinhan University, Eujungbu 11644, Korea
}

\section{과열수증기와 고압 처리를 이용한 불고기의 품질개선}

\author{
김은미 ${ }^{1 *} \cdot$ 서상희 $^{2} \cdot$ 최윤상 ${ }^{1} \cdot$ 전기홍 $^{1} \cdot$ 이은정 $^{3}$ \\ ${ }^{1}$ 한국식품연구원 표준화 연구본부, ${ }^{2}$ 한국식품의약품안전처 경인지청, \\ ${ }^{3}$ 신한대학교 식품조리과학부
}

\begin{abstract}
The objective of this study was to investigate the effect of superheated steam (SHS) and high hydrostatic pressure (HHP) techniques on the improvement of the quality of Bulgogi product during manufacturing process. Bulgogi product was treated with four different cooking/treatment process: conventional cooking (CC), SHS cooking (SHS), CC and then HHP cooking (CC-HHP), and SHS and HHP cooking (SHS-HHP) samples. SHS treated product increased moisture content, and decreased crude protein. Additionally, hardness, gumminess and shear force values were significantly different among the samples $(\mathbf{p}<\mathbf{0 . 0 5})$. In safety experiment after 14 days of storage at refrigeration temperature indicated that the bacterial population was lower in the case of SHS-HHP as compared to CC-HHP. Changes in texture during the storage periods at $10^{\circ} \mathrm{C}$ for SHS-HHP was lowest values with compared to the initial, while shear force values for both tended to decrease with increasing storage period. The TBA and VBN values for SHS-HHP increased to $0.48\left(5^{\circ} \mathrm{C}\right)-1.68\left(10^{\circ} \mathrm{C}\right) \mathrm{mg} \mathrm{MD} / \mathrm{kg}$ and $25.14\left(5^{\circ} \mathrm{C}\right)-45.14\left(10^{\circ} \mathrm{C}\right) \mathrm{mg} \%$, respectively after 15 days of storage. Overall, it was found that the combination of SHS and HHP reduced microbial growth, thus leading to improved product quality and sanitation.
\end{abstract}

Key words : superheated steam cooking, high hydrostatic pressure, Bulgogi

\section{서 론}

식품 산업에 있어서 가장 중요한 과제는 제품 유통 기간 중의 안전성과 제품 본연의 품질을 유지한 상태로 유통기한 을 연장하는 것으로 급격히 까다로워지는 소비자들의 요구 와 엄격해지는 식품 규정들은 식품 산업으로 하여금 안전성 확보는 물론 고품질 식품생산을 위한 새로운 가공법 개발을

*Corresponding author. E-mail : kem@kfri.re.kr Phone : 82-31-780-9287, Fax : 82-31-780-9059

Received 26 April 2017; Revised 17 July 2017; Accepted 17 August 2017.

Copyright (c) The Korean Society of Food Preservation. All rights reserved.
요구하고 있다(1). 경제 성장과 함께 식문화의 변화로 위생 적이며 기호성이 높은 식품에 대한 선호도가 증가하고 있음 에도 불구하고 기존의 제품들은 이를 만족시키지 못하고 있는 실정이며 새로운 가공기법을 이용한 제품개발 및 품질 개선을 할 수 있는 기술력 확보가 필요하다(2). 이와 관련하 여 활발히 연구되고 있는 것이 최소가공기술로 가장 많이 사용되고 있는 비열 가공기술인 고압 가공과 신속하고 경제 적인 공정인 과열 수증기 가공이 있다 $(2,3)$.

과열수증기를 이용한 가열은 포화증기를 $100^{\circ} \mathrm{C}$ 이상으 로 가열시 생성되는 과열수증기를 이용하는 가열방법으로 (4) $250-350^{\circ} \mathrm{C}$ 고온의 스팀을 이용해 단시간 내에 식품에 열을 전달하여 장시간 가열 조리 시 발생하는 영양소 손실 을 최소화 하고 식재료 고유의 맛, 향, 색, 질감 등을 최대한 
유지시키며 비타민 C 산화, 갈변 현상을 억제하고 미생물을 제어하는데 효과적인 것으로 나타났다(5). 과열 수증기 처 리가 식품에 활용된 연구 결과를 보면 짧은 가열 시간 동안 표면은 바삭하고 노릇하게 익혀주며, 지방의 함량을 낮추 고, 나트륨을 고르게 분포시켜 추가로 양념을 하지 않아도 되는 장점이 있는 것으로 보고되고 있다(6,7).

고압처리는 최근 식품에서 주목받고 있는 가공 기술 분 야로 식품의 보존성, 물성, 기능성을 향상시켜주며(8), 미생 물의 형태, 생화학적 반응, 세포막 및 세포벽에 영향을 주는 것으로 알려져 있다(9). 최초의 고압가공식품은 일본에서 출시되었으며 그 후 미국, 프랑스, 스페인 등에서 신제품이 출시되었고, 스페인에서는 고압 기술을 햄 산업에 이용해 살균 및 저장 안전성 효과를 얻고 있다(10). 고압처리 기술 은 제품의 외관과 향을 보존하는 비가열 공정으로 사용되었 으며(11), 포장된 식품에 처리하므로 고압 처리 후 미생물의 재감염 위험이 없는 장점을 가진 식품 살균기술로서 이미 국제식품규격위원회(12)와 미국 식품의약국(13)의 승인을 받았다.

한국을 대표하는 음식인 불고기는 한국을 찾는 외국인들 이 가장 선호하는 음식이며(14), 세계에서 가장 많이 소비되 는 한국음식으로 알려져 있다(15). 불고기는 쇠고기를 얇게 저며 양념 소스에 재운 뒤 석쇠나 불고기판에 구워 먹는 것을 말하며 양념 소스는 간장, 당류, 후춧가루를 기본으로 하고 각종양념(마늘, 생강, 파, 참기름 등)을 더하여 만든다 (16).

그러나 현재까지의 과열 수증기 조리공정에 대한 연구에 서는 양념이 첨가되지 않은 생고기 상태로 실행한 연구이거 나 고압살균기술을 복합적으로 사용하지 않은 상태의 연구 가 주로 실행되었다 $(6,10)$. 또한 편의식품용으로 개발된 양 념된 불고기는 미생물 관리와 조리의 편리성에 대한 문제점 으로 인해서 생산 및 유통에 어려움이 있다. 따라서 본 연구 는 편의식품용 불고기의 품질을 개선하고자 기존의 불고기 제조공정에 과열수증기 가열기술(SHS)과 고압살균기술 (HHP)을 적용하였을 때 품질개선효과 및 유통기간 연장효 과를 검토하였다.

\section{재료 및 방법}

\section{불고기 제조}

불고기(채끝살, 1++한우)는 $\operatorname{Kang}(1996)$ 의 레시피(Table 1)를 이용하여 제조하였다. 이 레시피는 이전 연구에서 외 국인과 내국인을 상대로 한 불고기 레시피의 기호 도를 조사한 결과 가장 선호도가 높은 것으로 나타났다. 레시피 에 포함된 모든 재료는 혼합 후 콜로이드밀(MKZA 6-5, Masko sangyo, Osaka, Japan)을 통과시켜 곱게 갈아 사용하 였다(17). 소스에 재운 불고기를 일반조리(CC), 일반조리와
초고압 병행 처리(CC-HHP), 과열수증기 조리(SHS), 과열 수증기와 초고압 병행 처리(SHS-HHP)로 각각 다르게 처리 하여 실험에 사용하였다. 각 실험구는 저장 중에 품질변화 를 조사하기 위하여 각각 해당 처리를 마친 후, polyethylene 포장기에 넣어 냉장 조건 $5^{\circ} \mathrm{C}$ 와 $10^{\circ} \mathrm{C}$ 에 15 일 간 저장하면서 품질변화를 조사하였다.

일반 조리는 일반 불고기제조공정과 같이 팬을 이용하여 조리(중불, 끓고 4 분간 추가 가열)하였으며, 과열수증기 조 리는 Superheated steam(DFC-240W, Naomoto, Osaka, Japan)기기를 이용하여 오븐: $200^{\circ} \mathrm{C}$, 스팀: $300^{\circ} \mathrm{C}, 5$ 분으로 설정 후 조리하였다. 고압 처리는 QFP 215L-600(Avure technology Inc., Columbus, OH, USA)은 일반적으로 $500-600 \mathrm{Mpa}, 1-2$ 분을 이상적인 품질 유지 조건이며(18), 본 연구는 $500 \mathrm{Mpa} 3$ 분으로 설정하여 실시하였다. 이때 일부 시료를 채취하여 SEM 전자 현미경으로 관찰을 시도 하였다.

Table 1. Formula of Bulgogi sacuce

\begin{tabular}{cc}
\hline Ingredient & $\%$ \\
\hline Soy sauce & 19.50 \\
White sugar & 16.04 \\
Chopped garlic & 6.92 \\
Chopped spring onion & 6.92 \\
Water & 6.60 \\
Grated pear & 24.53 \\
Black pepper powder & 0.31 \\
Sesame oil & 9.75 \\
Ginger juice & 1.26 \\
Honey & 6.29 \\
Roasted sesame & 1.88 \\
\hline sum & 100.00 \\
\hline
\end{tabular}

\section{일반 성분 분석}

$\mathrm{AOAC}(1995)$ 방법에 따라 수분은 $105^{\circ} \mathrm{C}$ 상압가열건조법 으로 측정하였고, 조회분은 $550^{\circ} \mathrm{C}$ 회화로에서 직접 회화시 켜 중량법으로 정량하였다(19). 조지방은 Soxhlet 추출법으 로 측정하였고, 조단백은 Kjeltec system(Kjeltec system, Kjeltec auto sampler system 8400 analyzer, Foss Tecator, Stockholm, Sweden)을 이용하였다.

색 도

색도는 색차계(spectrophotometer CM-2500d, Konica minolta, Osaka, Japan)를 사용하여 L값(lightness), a 값 (redness), $\mathrm{b}$ 값(yellowness)로 나타내었다(표준판 $\mathrm{L}=69.08$, $a=-0.78, b=14.39$ ). 


\section{조직감}

조직감은 texture analyzer(TA-XT2, stable Micro systems Ltd., Godalming, UK)를 사용하여 지름 $2.5 \mathrm{~cm}$ 인 aluminum cylinder probe(pretest: $3.0 \mathrm{~mm} / \mathrm{s}$, test: $1.0 \mathrm{~mm} / \mathrm{s}$, post: 1.0 $\mathrm{mm} / \mathrm{s}$ 로 경도, 응집성, 부착성, 검성, 씹힘성을 측정하였다. 전단력은 warner-bratzler blade(pretest: $2.0 \mathrm{~mm} / \mathrm{s}$, test: 2.0 $\mathrm{mm} / \mathrm{s}$, post: $5.0 \mathrm{~mm} / \mathrm{s}$ )를 사용하여 측정하였다. 저장 기간에 따른 조직감의 변화는 texture analyzer(TA.XT Express, Stable Micro System Ltd, Godalming, UK)를 이용하여 전단 력(warner-bratzler blade \#31)을 측정하였다.

\section{총균수 측정}

총균수는 $3 \mathrm{M}$ 건조필름(Petrifilm ${ }^{\mathrm{TM}}$ plate, $3 \mathrm{M}$ Co., St. Paul, MN, USA)을 이용하여 진행하였으며, $35^{\circ} \mathrm{C}$ 배양기에 서 48시간 배양한 후 $25-250$ 개의 집락을 형성한 평판을 택하여 $\mathrm{g}$ 당 집락수를 계산하였다.

\section{$\mathrm{pH}$}

$\mathrm{pH}$ 는 시료 $10 \mathrm{~g}$ 을 취하여 $90 \mathrm{~mL}$ 의 증류수에 희석한 후 filter paper(Whatman ${ }^{\mathrm{TM}}$ cellulose filter paper Grade 1, GE Healthcare companies, Buckinghamshire, UK)로 여과하여, $\mathrm{pH}$ meter(Orion 3-star plus $\mathrm{pH}$ Benchtop meter, Orion Research Inc., Boston, MA, USA)를 이용하여 측정하였다.

\section{Thiobarbituric acid reactive substances(TBA)} 측정

시료 $5 \mathrm{~g}$ 에 butylated hydroxyanisole(BHA)와 증류수를 첨가하여 균질화 시킨 후 균질액 $1 \mathrm{~mL}$ 을 시험관에 넣고 thiobarbituric acid(TBA)/trichloroacetic acid(TCA) 혼합용액 $2 \mathrm{~mL}$ 을 넣어 완전히 혼합한 후 $90^{\circ} \mathrm{C}$ 의 항온수조에서 15 분 간 열처리하였다. 열처리 후 냉각시켜 $3,000 \mathrm{rpm}$ 에서 10 분 간 원심분리한 시료의 상층을 회수하여 $531 \mathrm{~nm}$ 에서 측정한 흡광도에 5.88을 곱하여 $\mathrm{mgMA}$ (malondialdehyde) $/ \mathrm{kg}$ 으로 나타냈다.

\section{Volatile basic nitrogen (VBN)}

VBN은 시료 $5 \mathrm{~g}$ 에 증류수 $45 \mathrm{~mL}$ 를 가하여 균질화한 후 Whatman No. 1(Whatman filer paper Grade 1, Whatman international Ltd., Maidstone, England)으로 여과하였다. Conway unit 접착부에 glycerin을 바르고 여액 $1 \mathrm{~mL}$ 을 Conway dish 외실에 넣고, 내실에는 $0.005 \mathrm{~N} \mathrm{H}_{2} \mathrm{SO}_{4} 1 \mathrm{~mL}$ 을 넣고 $25^{\circ} \mathrm{C}$ 에서 1 시간 정치하였다. 정치 한 후 내실에 Brunswik 시액을 첨가한 후 $0.01 \mathrm{~N} \mathrm{NaOH}$ 로 적정하였다.

\section{통계분석}

분석 결과는 평균값 \pm 표준편차 $(m e a n \pm S D)$ 로 표시하였으 며 통계 처리는 SPSS(Statistics Package for the Social Science, Ver. 18.0 for windows, SPSS Inc., Chicago, IL,
USA) 프로그램을 이용하여 one-way ANOVA를 실시하였 으며, Tukey's test로 $\mathrm{p}<0.05$ 수준에서 유의성을 검증하였다.

\section{결과 및 고찰}

\section{일반 성분 분석}

$\mathrm{CC}, \mathrm{SHS}, \mathrm{CC}-\mathrm{HHP}$ 및 SHS-HHP에 대해 일반성분을 분석 한 결과는 Table 2 에서와 같다. 수분은 $\mathrm{CC}$ 에 비해 SHS와 SHS-HHP 불고기가 높은 함량으로 분석되었으며, 조단백 질은 $\mathrm{CC}$ 불고기가 다른 처리구에 비해 높은 함량을 보였다. 조지방은 15.95(SHS)-19.72(SHS-HHP)\%의 범위로 분석되 었으며, 조회분은 CC 불고기가 가장 높은 함량을 보였다.

SHS 조리 시 스팀에 의한 시료의 보수력 증가로 수분함 량이 높게 측정된 것으로 사료되며, 이는 닭고기에 과열 증기를 처리한 선행 연구 결과와 비슷한 경향이었다 $(20,21)$.

Table 2. Proximate composition of Bulgogi

$(\%)$

\begin{tabular}{ccccc}
\hline Treatments $^{\mathrm{l})}$ & Moisture & Crude protein & Crude fat & Crude ash \\
\hline CC & $50.96 \pm 0.32^{2 \mathrm{bb3})}$ & $21.74 \pm 0.56^{\mathrm{b}}$ & $16.69 \pm 0.62^{\mathrm{a}}$ & $2.17 \pm 0.28^{\mathrm{b}}$ \\
CC-HHP & $45.94 \pm 0.06^{\mathrm{a}}$ & $19.44 \pm 0.02^{\mathrm{a}}$ & $17.13 \pm 0.46^{\mathrm{a}}$ & $1.54 \pm 0.01^{\mathrm{ab}}$ \\
SHS & $53.34 \pm 0.52^{\mathrm{b}}$ & $19.61 \pm 0.03^{\mathrm{a}}$ & $15.95 \pm 0.09^{\mathrm{a}}$ & $1.84 \pm 0.35^{\mathrm{b}}$ \\
SHS-HHP & $53.41 \pm 0.40^{\mathrm{b}}$ & $19.44 \pm 0.02^{\mathrm{a}}$ & $19.72 \pm 0.18^{\mathrm{b}}$ & $1.01 \pm 0.03^{\mathrm{a}}$ \\
\hline
\end{tabular}

${ }^{1)} \mathrm{CC}$, conventional cooking; CC-HHP, conventional cooking+high hydrostatic pressure; SHS, superheated steam cooking; SHS-HHP, superheated steam cookingthigh hydrostatic pressure.

${ }^{2)}$ Values are mean $\pm \mathrm{SD}$

${ }^{3)}$ Different letters in a column means significat different at $\mathrm{p}<0.05$.

\section{색 도}

각 처리구에 따른 색도를 측정한 결과 $\mathrm{L}$ 값은 $\mathrm{CC}$ 조리구 가 낮은 값을 보였으며, $\mathrm{a}$ 값과 $\mathrm{b}$ 값은 유의적인 차이를 보이지 않았다. Chun 등(20)은 과열증기 처리한 닭고기 시 료가 처리하지 않은 시료에 비해 $\mathrm{L}$ 값은 감소하고 $\mathrm{a}$ 와 $\mathrm{b}$ 값이 증가하였다고 보고하였다. 그러나 돼지고기에 $\mathrm{HHP}$ 의 압력을 증가하여 처리할수록 $\mathrm{L}$ 값과 $\mathrm{a}$ 값은 증가하고, $\mathrm{b}$ 값은 유의적 차이를 보이지 않는다고 보고하여 본 결과와 상이 한 것을 알 수 있었다(22). 이는 시료 처리에 따른 결과라고 생각되며, 본 연구의 특성 상 색도의 변화는 고기 고유의 색보다 첨가된 양념에 크게 영향을 받는 것으로 여겨진다. 이는 초고압 처리를 통해 생육의 육색변화는 명 확하게 차이를 보이나, 가열육의 경우 육색 변화는 유의적 차이가 없다는 보고와 일치하였다(23).

\section{조직감}

처리구별 조직감을 측정한 결과는 Table 4 와 같다. 측정 
Table 3. Color of Bulgogi

\begin{tabular}{cccc}
\hline Treatments $^{1)}$ & $\mathrm{L}$ & $\mathrm{a}$ & $\mathrm{b}$ \\
\hline CC & $48.83 \pm 1.53^{2 \mathrm{a} a 3)}$ & $4.61 \pm 0.41$ & $13.55 \pm 0.87$ \\
CC-HHP & $51.76 \pm 1.39^{\mathrm{ab}}$ & $4.54 \pm 0.28$ & $13.28 \pm 0.88$ \\
SHS & $51.92 \pm 1.44^{\text {ab }}$ & $4.38 \pm 0.32$ & $13.77 \pm 1.50$ \\
SHS-HHP & $53.84 \pm 1.19^{\mathrm{b}}$ & $3.98 \pm 0.06$ & $13.14 \pm 0.65$ \\
\hline
\end{tabular}

${ }^{1)} \mathrm{CC}$, conventional cooking, CC-HHP, conventional cooking+high hydrostatic pressure; SHS, superheated steam cooking; SHS-HHP, superheated steam cookingthigh hydrostatic pressure.

${ }^{2)}$ Values are mean \pm SD.

${ }^{3)}$ Different letters in a column means significat different at $p<0.05$.

결과 경도는 $\mathrm{CC}$ 가 $12.92 \mathrm{~kg}$ 으로 가장 낮은 값을 보였으며 SHS 조리구가 $17.07 \mathrm{~kg}$ 로 높은 값을 보였다. 탄력성, 응집성 과 씹힘성은 시료간 유의적 차이는 보이지 않았으며, 전단 력은 SHS-HHP 처리구가 $29.99 \mathrm{~kg}$ 으로 가장 높게 측정되었 다. 이러한 결과는 초고압 처리에 따른 닭고기의 조직감을 측정한 결과 초고압 처리시 경도가 증가한다는 결과와 일치 하였다(24).

\section{SEM측정}

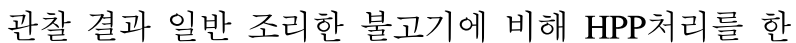
불고기의 조직이 부서진 것을 볼 수 있었다(Fig. 1). SHS공 정을 거친 불고기는 HPP 처리공정보다 조직의 부서짐은 덜하였지만 비교적 조직이 촘촘하게 배열된 일반조리와
차이를 보였다. SHS와 HPP공정을 모두 거친 불고기는 일 반조리 공정의 불고기와 비슷한 구조를 보이는 것을 볼 수 있었으나 일반조리보다는 조직 간의 구분이 비교적 확실 한 것을 확인 할 수 있었다.

\section{미생물 분석}

$\mathrm{CC}-\mathrm{HHP}$ 와 SHS-HHP 처리를 한 불고기를 $5^{\circ} \mathrm{C}$ 와 $10^{\circ} \mathrm{C}$ 에 서 14 일 동안 저장하면서 총균수를 검사하였다(Fig. 2). 저 장기간이 경과할수록 총균수는 증가하는 값을 보였으며 $\mathrm{CC}-\mathrm{HHP}$ 는 $2.13 \log \mathrm{CFU} / \mathrm{g}\left(0\right.$ 일)-6.72 $\log \mathrm{CFU} / \mathrm{g}\left(14\right.$ 일, $10^{\circ} \mathrm{C}$ ) 로 증식하였으며 SHS-HHP는 $1.00 \log \mathrm{CFU} / \mathrm{g}(0$ 일)-3.19 $\mathrm{log}$ $\mathrm{CFU} / \mathrm{g}\left(14\right.$ 일, $\left.10^{\circ} \mathrm{C}\right)$ 로 나타났다. 연구 결과 SHS-HHP가 CC-HHP에 비해 균의 증가가 1-3 log 정도 억제되어 안전성 확보에 긍정적인 영향을 주는 것을 알 수 있었다. 이는 선행 연구 결과와 같았으며(26), SHS 처리가 식품 오염을 감소시 킬 수 있는 효과적인 처리 방법임을 확인하였다.

\section{$\mathrm{pH}$, texture}

$\mathrm{CC}-\mathrm{HHP}$ 의 저장 초기 $\mathrm{pH}$ 는 5.91으로 측정되었으며 저장 기간에 따라 감소하는 경향을 보여 $10^{\circ} \mathrm{C}$ 저장시 15 일 후 5.83 감소하였다(Fig. 3). SHS-HHP는 초기 5.82에서 $10^{\circ} \mathrm{C}$ 에 서 15 일 동안 저장시 5.03으로 감소하는 것을 볼 수 있었다. 두 시료 모두 $\mathrm{pH}$ 는 감소하는 경향을 보였으나 큰 변화는 나타나지 않았다.

Table 4. Texture profile analysis of Bulgogi depending on processing method

\begin{tabular}{ccccccc}
\hline Treatments $^{1)}$ & Hardness $(\mathrm{kg})$ & Spriginess & Cohesiveness & Gumminess & Chewiness & Shear force $(\mathrm{kg})$ \\
\hline CC & $12.92 \pm 0.55^{22 \mathrm{a} 3)}$ & $0.81 \pm 0.05$ & $0.55 \pm 0.04$ & $7.13 \pm 0.49^{\mathrm{a}}$ & $5.76 \pm 0.61$ & $20.40 \pm 1.54^{\mathrm{a}}$ \\
CC-HHP & $15.79 \pm 1.06^{\mathrm{ab}}$ & $0.74 \pm 0.07$ & $0.55 \pm 0.05$ & $8.75 \pm 1.23^{\mathrm{b}}$ & $6.47 \pm 1.32$ & $25.98 \pm 1.18^{\mathrm{ab}}$ \\
SHS & $17.07 \pm 0.99^{\mathrm{b}}$ & $0.71 \pm 0.04$ & $0.55 \pm 0.02$ & $9.35 \pm 0.47^{\mathrm{b}}$ & $6.67 \pm 0.72$ & $24.85 \pm 7.22^{\mathrm{ab}}$ \\
SHS-HHP & $16.75 \pm 0.33^{\mathrm{ab}}$ & $0.74 \pm 0.04$ & $0.59 \pm 0.03$ & $9.80 \pm 0.58^{\mathrm{b}}$ & $7.24 \pm 0.51$ & $29.99 \pm 0.62^{\mathrm{b}}$ \\
\hline
\end{tabular}

${ }^{11} \mathrm{CC}$, conventional cooking; CC-HHP, conventional cooking thigh hydrostatic pressure; SHS, superheated steam cooking; SHS-HHP, superheated steam cooking+high hydrostatic pressure.

${ }^{2)}$ Values are mean \pm SD.

${ }^{33}$ Different letters in a column means significat different at $\mathrm{p}<0.05$.
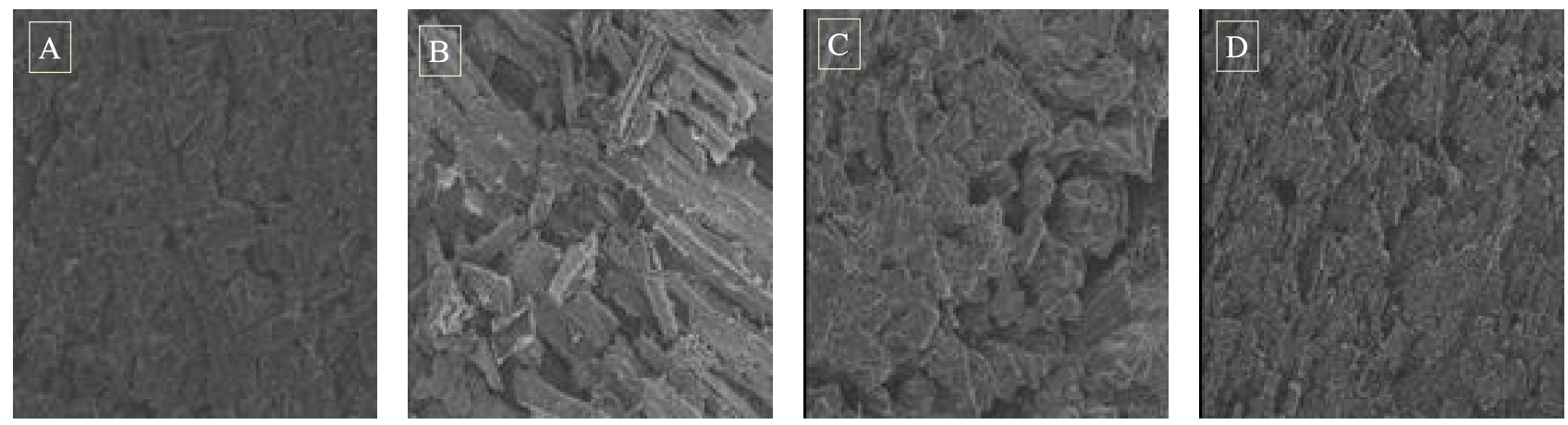

Fig. 1. SEM of Bulgogi structures treated with (A) conventional cooking (CC), (B) conventional cooking+high hydrostatic pressure (CC-HHP), (C) superheated steam cooking, (D) superheated steam cooking+high hydrostatic pressure. 


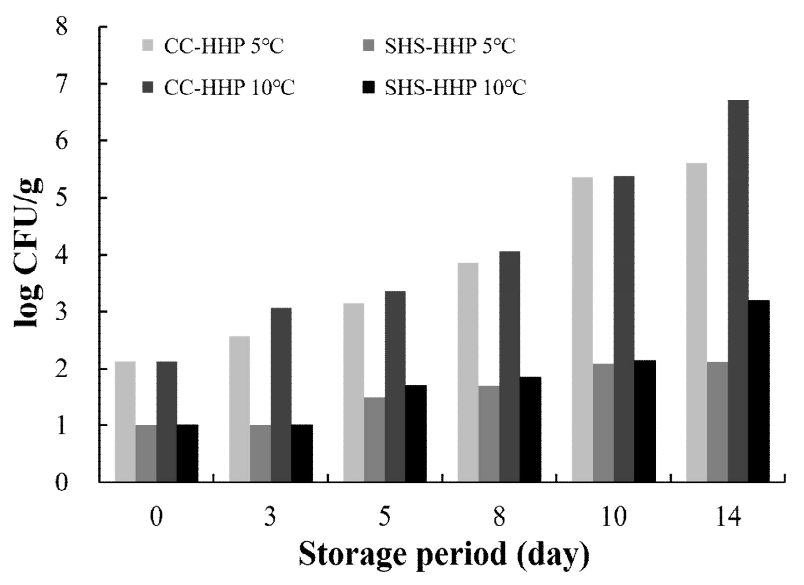

Fig. 2. Total bacterial number of Bulgogi treated with various processing during storage period.

CC-HHP, conventional cooking+high hydrostatic pressure SHS-HHP, superheated steam cooking+high hydrostatic pressure.

전단력을 측정한 결과 저장기간이 지나면서 감소하는 경향을 보였으며(Fig. 4) SHS-HHP가 CC-HHP에 비해 느리 게 감소하는 것을 볼 수 있었다. 본 연구 결과 조직감의 변화가 비교적 적은 SHS-HHP 시험군이 조직감 측면에서 품질안정성을 확보할 수 있을 것으로 생각되었다.

\section{TBARS}

저장 온도와 기간에 따른 TBARS값의 변화는 Fig. 5와 같다. 지방 산패도 값인 TBARS는 일반적으로 저장기간이 길어질수록 증가하며 본 실험에서도 증가하였다.

$\mathrm{CC}-\mathrm{HHP}$ 의 초기값은 $0.52 \mathrm{mg} \mathrm{MA} / \mathrm{kg}$ 으로 측정되었으며 15 일 저장시 $10^{\circ} \mathrm{C}$ 에서 $1.72 \mathrm{mg} \mathrm{MA} / \mathrm{kg}$ 값으로 측정되었다. SHS-HHP는 $0.48\left(0\right.$ 일) $-1.68\left(15\right.$ 일, $\left.10^{\circ} \mathrm{C}\right) \mathrm{mg} \mathrm{MA} / \mathrm{kg}$ 의 값을 나타내었으며 CC-HHP에 비해 상대적으로 낮은 값을 보였

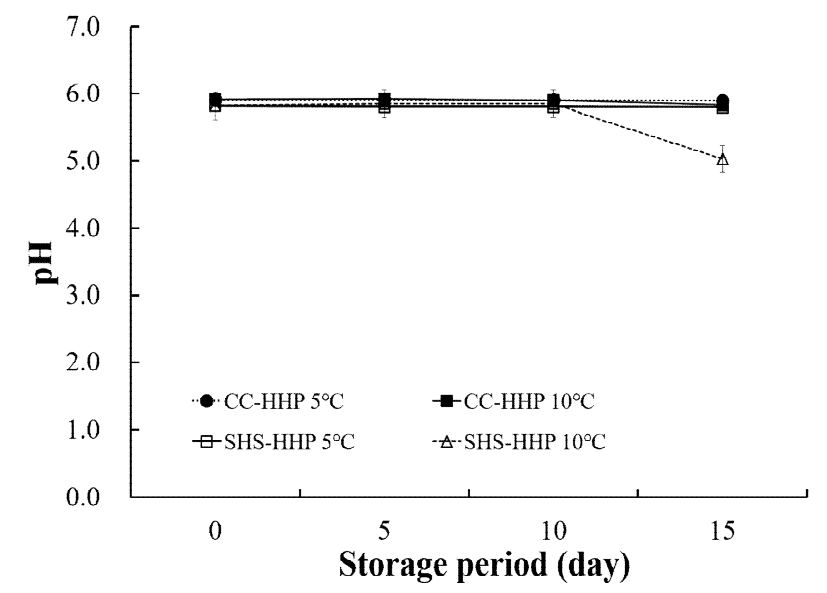

Fig. 3. Changes in $\mathrm{pH}$ value of Bulgogi treated with various processing during storage period.

CC-HHP, conventional cooking+high hydrostatic pressure SHS-HHP, superheated steam cookingthigh hydrostatic pressure.

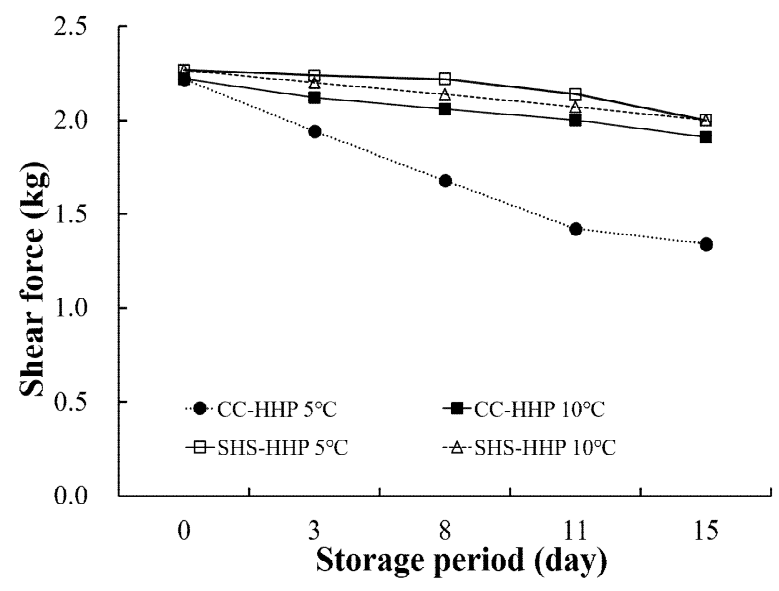

Fig. 4. Changes in texture of Bulgogi treated with various processing during storage period.

CC-HHP, conventional cookingthigh hydrostatic pressure SHS-HHP, superheated steam cooking+high hydrostatic pressure.

다. 일반적으로 식육에서 TBA 값은 $0.46 \mathrm{mg} \mathrm{MA} / \mathrm{kg}$ 이하까 지는 가식권으로 인정하고 $1.2 \mathrm{mg} \mathrm{MA} / \mathrm{kg}$ 이상일 때는 부패 된 것으로 인정할 수 있다고 하였으며(27), Brewer 등(28)은 $4.0 \mathrm{mg} \mathrm{MA} / \mathrm{kg}$ 이상은 완전히 산패된 것으로 평가하였다. $5^{\circ} \mathrm{C}$ 에서 2주간 저장한 본 연구의 TBARS 값은 $1.01 \mathrm{mg}$ $\mathrm{MA} / \mathrm{kg}$ 로 다소 높은 값을 보였는데 이는 식육 자체의 산패 보다는 저온 숙성시 양념 소스의 발효 정도의 차이에 의한 것으로 여겨지며, 한국 전통소스로 숙성된 고기가 높은 TBARS 값을 가지는 선행 결과와 같은 경향이었다(29).

\section{VBN}

저장기간 중의 $\mathrm{VBN}$ 값은 CC-HHP는 초기 $26.15 \mathrm{mg} \%$ 에 서 $10^{\circ} \mathrm{C}$ 에서 15 일 저장 후 $46.14 \mathrm{mg} \%$ 로 그 값이 증가하였 으며 SHS-HHP 또한 $25.14\left(0\right.$ 일)- $45.14 \mathrm{mg} \%\left(15\right.$ 일, $\left.10^{\circ} \mathrm{C}\right)$ 으

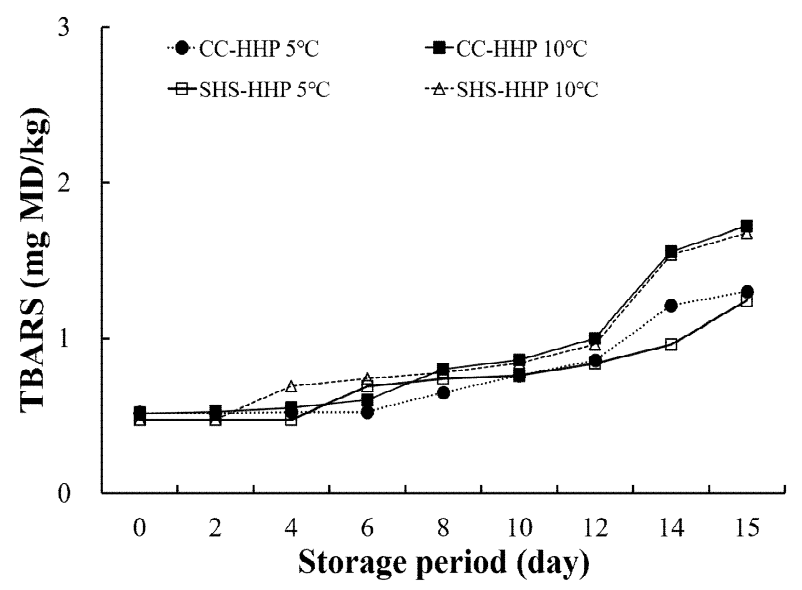

Fig. 5. Changes in TBARS value of Bulgogi treated with various processing during storage period.

CC-HHP, conventional cooking+high hydrostatic pressure SHS-HHP, superheated steam cooking+high hydrostatic pressure. 
로 증가하였으며 상대적으로 작은 값을 보였다(Fig. 6). 육 류의 신선도를 평가하는데 많이 사용되는 VBN값은 저장일 수에 따라 서서히 증가하는데 Park 등(30)은 저장 중에 근육 단백질이 아미노산과 그 외에 여러 가지 무기태질소를 분해 하는데 이는 단백질의 가수분해에 따른 아미노산과 펩타이 드의 증가에 의해 $\mathrm{VBN}$ 이 증가하고, adenosyl monophosphate (AMP)의 분해에 따른 암모니아 생성과 nucleotide 의 증가 에 의해서도 영향을 받는다고 보고하였다.

$\mathrm{VBN}$ 의 값은 식품 공전상 $20 \mathrm{mg} \%$ 이하로(31), 농촌진흥 청 축산과학원은 $30 \mathrm{mg} \%$ 이하일 경우 신선육으로 규정하 고 있다(32). 본 실험 결과는 저장 기간 동안 기준보다 높은 값을 보였으나, 양념 돈육을 저장하면서 품질 변화를 연구 한 선행연구 결과들과 일치하였다 $(3,29,33,34)$. 이러한 결과 는 식육자체에 의한 것보다 양념에 의한 영향이 상대적으로 크게 작용한 결과로 사료된다.

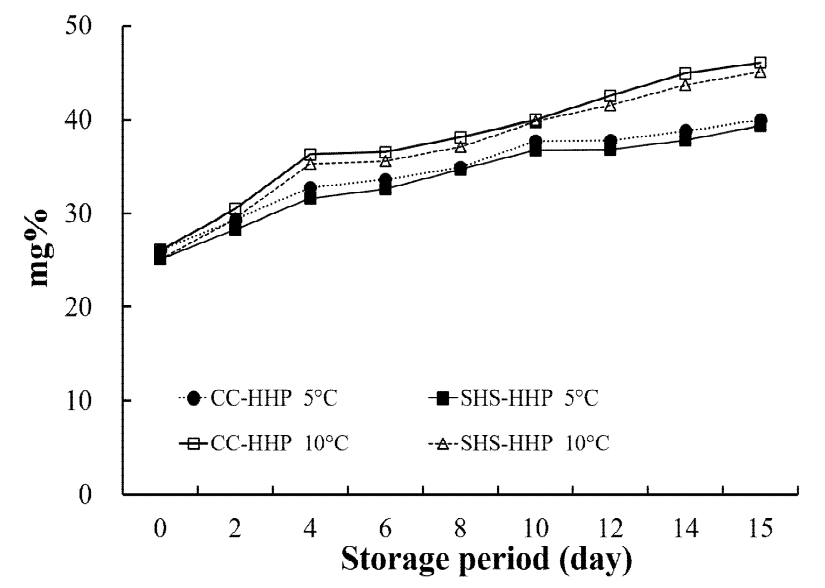

Fig. 6. Changes in VBN value of Bulgogi treated with various processing during storage period.

CC-HHP, conventional cooking+high hydrostatic pressure SHS-HHP, superheated steam cooking+high hydrostatic pressure.

\section{요 약}

본 연구는 불고기에 SHS와 HPP 기술을 적용하여 냉장온 도 $\left(5,10^{\circ} \mathrm{C}\right)$ 에서 저장하면서 그 품질변화를 살펴보았다. SHS 조리가 일반조리에 비해 다즙성과 조직감(연한 정도) 가 향상되는 것을 알 수 있었다. 이것은 조직감 측정결과와 같은 경향으로 SHS 조리가 일반조리에 비해 조직이 연해져 부드러운 조직감을 부여하는 것을 알 수 있었다. 또한 총균 수의 증가폭도 일반 조리구에 비해 적은 것을 확인할 수 있었으며 지방 산패도 값인 TBA 또한 SHS-HHP병행 처리 군이 일반 조리에 비해 낮은 값을 보여 안전성을 확보할 수 있을 것으로 사료되었다. 식육의 신선도를 나타내는 VBN 은 간장 양념으로 인해 높은 값을 보여 본 연구의 특성상 VBN 함량만으로 신선도 정도를 판단하기는 어려울
것으로 사료된다.

이상의 결과로 기존의 불고기 제품에 SHS 기술과 HPP 기술의 적용으로 제품의 품질향상을 통한 조직감 상승과 유통기간 연장효과를 어느 정도 기대할 수 있는 것으로 생각되었다.

\section{감사의 글}

본 연구는 2015년 농림축산식품부 고부가가치식품기술 개발사업(과제번호: 315068-3)과 2016년 한국식품연구원 주요사업의 지원에 의해 이루어진 것이며 이에 감사드립니 다.

\section{References}

1. Park JY, Na SY, Lee YJ (2010) Present and future of non-thermal food processing technology. Food Science and Industry, 43, 2-20

2. Park JY (2009) High-hydrostatic pressure pasteurization. Food Industry, 210, 9-23

3. Lee SJ, Kim CJ, Cho YJ (2000) Hydration and texture characteristics of Brown rice treated with superheated steam process. J Korean Soc Food Sci Nutr, 29, 1190-1194

4. Mujumdar AS (2006) Superheated Steam Drying. Handbook of Industrial Drying. 2nd ed. CRC Press, Boca Raton, Florida, USA, p 1071-1086

5. Choi Y, Oh JH, Bae IY, Cho EK, Kwon DJ, Park HW, Yoon S (2013) Changes in quality characteristics of seasoned soy sauce treated with superheated steam and high hydrostatic pressure during cold storage. Korean J Food Cook Sci, 29, 387-398

6. Sila DN, Smout C, Vu ST, Loey AV, Hendrickx M (2005) Influence of pretreatment conditions on the texture and cell wall components of carrots during thermal processing. J Food Sci, 70, 85-91

7. Oh JH, Yoon S, Choi Y (2014) The effect of superheated steam cooking condition on physico-chemical and sensory characteristics of chicken breast fillets. Korean J Food cookery Sci, 30, 317-324

8. Park SJ, Choi YB, Ko JR, Kim YE, Lee HY (2014) Enhancement of antioxidant activities of blueberry (Vaccinium ashei) by using high-pressure extraction process. J Korean Soc Food Sci Nutr, 14, 471-476

9. Kwon SM, Kim CM, Kim YH (2007) Biological 
characteristics of instant rice treated with high hydrostatic pressure. Food Science and Industry, 40, 31-35

10. Koo SY, Cha KH, Lee DU (2007) Effects of high hydrostatic pressure on foods and biological system. Food Science and Industry, 40, 23-30

11. Swientek RJ (1992) High hydrostatic pressure for food preservation. Food Process, 53, 90-91

12. CAC (2007) Guidelines on the application of general principles of food hygiene to the control of Listeria monocytogenes in foods. (accessed April 2015)

13. HHS. Guidance for Industry: Control of Listeria monocytogenes in Refrigerated or Frozen Ready-to-eat Foods. http://www.fda.gov/Food/NewsEvents/Constituent Updates/ucm047255.htm. (accessed April 2015)

14. Kweon SY, Yoon SJ (2006) Recognition and preference to Korean traditional food of Chinese at Seoul Residence. Korean J Food Cult, 21, 17-30

15. Chang MJ, Cho MS (2000) Recognition and preference to Korean traditional food of foreign visitors in Korea. J Korean Soc Food Culture, 15, 215-223

16. Jo SG (2014) Sensory characteristics and cross-cultural consumer acceptability of Bulgogi. MS Thesis, Ewha Womans University, Korea, p 23-29

17. Kang IH (1996) Korean taste. Daehan publishing company, Seoul, Korea, p 76

18. Timmermans RAH, Mastwijk HC, Knol JJ, Quataert MCJ, Vervoort L, der Plancken IV, Hendrickx ME, Matser AM (2011) Comparing equivalent thermal, high pressure and pulsed electric field processes for mild pasteurization of orange juice. Part I: Impact on overall quality attributes. Innovative Food Sci Emerging Technol, 12, 235-243

19. AOAC (1995) Official Methods of Analysis. $16^{\text {th }}$ ed, Association of Official Analytical Chemists, Washington DC, USA, p 69-74

20. Chun JY, Kwon BG, Lee SH, Min SG, Hong GP (2013) Studies on physico-chemical properties of chicken meat cooked in electric oven combined with superheated steam. Korean J Food Sci, 33, 103-108

21. Mora B, Curti E, Vittadini E, Barbanti D (2011) Effect of different air/steam cooking methods on turkey breast meat: Physical characterization, water status and sensory properties. Meat Sci, 88, 489-497

22. Hong GP, Park SH, Kim JY, Lee SK, Min SG (2005) Effect of time dependent high pressure treatment on physico-chemical properties of pork. Food Sci Biotechnol, $14,808-812$
23. Jung SM, Kang MG, Kim IS, Nam KC, Ahn DU, Jo CR (2012) Effect of addition of phosvitin and high pressure processing on microbiological quality and lipid and protein oxidation of minced chicken meat. Korean J Food Sci Ani Resour, 32, 212-219

24. Kruk ZA, Yun HJ, Rutley DL, Lee EJ, Kim YJ, Jo CR (2011) The effect of high pressure on microbial population, meat quality and sensory characteristics of chicken breast fillet. Food Control, 22, 6-12

25. Crehan CM, Troy DJ, Buckley DJ (2000) Effects of salt level and high hydrostatic pressure processing on frankfurters formulated with 1.5 and $2.5 \%$ salt. Meat Sci, 55, 123-130

26. Kondjoyan A, Portanguen S (2008) Effect of superheated steam on the inactivation of Listeria innocua surfaceinoculated onto chicken skin. J Food Eng, 87, 162-171

27. Turner EW, Paynter WD, Montie EJ, Bessert MW, Struck GM, Olson FC (1954) Use of the 2-thiobarbituric acid reagent to measure rancidity in frozen pork. Food Technol, 8, 326-330

28. Brewer MS, Ikins WG, Harbers CAZ (1992) TBA values, sensory characteristics, and volatiles in ground pork during long term frozen storage effects of packaging. J Food Sci, 57, 558-563

29. Moon SS, Jin SK, Kim IS, Park KH, Hah KH (2006) Changes of TBARS, VBN and pathogens on vacuum packed pork during storage after aging with Korean traditional sauces. Korean J Food sci Ani Resour, 26, 322-330

30. Park GB, Kim YJ, Lee HG, Kim JS, Kim YH (1988) Changes in freshness of meats during postmortem storage. I. Changes in freshness of pork. Korean J Animal Sci, 30, 561-566

31. Yang HS, Jeong JY, Choi YH, Joo ST, Park GB (2009) Effect of different packaging methods on the quality and storage characteristics of domestic broiler breast meat during cold storage. Korean J Poult Sci, 36, 69-75

32. National Institute of Animal Science (2007) Analysis methods of animal resources food. National Institute of Animal Science, Suwon, Korea, p 111

33. Choi WS, Lee KT (2002) Quality changes and shelf-life of seasoned pork with soy sauce or Kochujang during chilled storage. Korean J Food Sci Ani Resour, 22, 240-246

34. Lee KS, Park KS, Park HS, Choi YJ, Park SS, Jung IC, Moon YH (2011) Changes in quality of pork meat seasoned with red wine during storage. J East Asian Soc Diet Life, 21, 74-81 